\title{
A CULTURA LATINA NO ESPAÇO PORTUGUES
}

\section{Guilhermino Cesar}

Na Teoria da História da Literatura Portuguêsa (Dissertação para o concurso da 3a cadeira de Literaturas Modernas da Europa, do Curso Superior de Letras), afirma Teófilo Braga tê-la escrito para demonstrar o seguinte: «Na luta entre as tradições latinas e o gênio das literaturas da Idade Média, a Literatura Portuguêsa foi a que mais sacrificou o caráter nacional ao classicismo e a que mais perdeu da sua originalidade».*

Eis uma tese digna de meditação. O grande crítico enunciou-a em têrmos absolutamente claros, mas demasiado imprudentes. Para demonstrá-la, baseou-se em premissas como esta:

«Os reis portuguêses, ligados com a aristocracia asturoleonesa, a quem davam o senhorio dos castelos, cometeram o êrro desastroso de sacrificarem a vida e criação moçárabe à caduca civilização romana» (p. 16).

Cita, como conseqüência imediata dessa submissão, a perda da «originalidade linguística», ao ponto de Camões dizer, n'Os Lusiadas, da língua portuguêsa: «... na qual, quando imagina, / com pouca corrupção crê que é a latina» (p. 17).

João de Barros, o autor das Décadas, salvou-se porém do modêlo romano de Tito Lívio, da sua retórica. De que maneira? Escreve Teófilo:

«João de Barros escapou a êste perigo pelo mesmo meio que salvou Camões do classicismo: visitando o lugar da ação, e tomando parte direta como herói» (p. 17).

Segundo, ainda, o seu ponto de vista, a romanização das leis e dos costumes, na terra lusitana, redundou na submissão

* - Obra e autor cit. Pôrto, Imprensa Portuguêsa, Editôra, 1872, p. 6. 
dos gêneros literários aos cânones originários de Roma, no ponto de «o domínio autoritário do latim, forma materializada da civilização romana, tornar-se quase intolerante» (p. 18).

«Daqui fomos levados - acrescenta - à intolerância religiosa, ao cesarismo romano, que atingiu o seu esplendor em D. João $\mathrm{V}$ e se formulou em doutrina política durante o govêrno do Marquês de Pombal. A consequiência foi inocularmos em nós o vício da civilização romana: o indivíduo ficou nulo diante da ação do Estado; o agente despertador da nacionalidade, o mar, tornou-se apenas uma barreira, e assim acabada a vida histórica dêste povo, representamos a nossa inanidade na pobreza e falta de idéia na literatura» (p. 18).

Em linhas gerais, êste o pensamento de Teófilo Braga, que omite, porém, as vantagens decorrentes da assimilação da civilização romana. Ora, se esta foi «vício» generalizado, - pois quase todo o Ocidente europeu se deixou vencer por ela, - representou também o molde em que povos bárbaros fundiram novos destinos, humanizaram seus costumes, ordenaram a vida civil segundo formas mais evoluídas, permitindo afinal que o indivíduo emergisse do clã e da horda com os seus direitos pessoais reconhecidos e amparados por instituições adequadas.

De outra parte, atribui o crítico ao cesarismo de D. João V e Pombal qualidade negativa, no concernente à criação literária, quando ocorreu justamente o oposto. Pois, nos dois longos reinados - joanino e josefino - as letras conheceram verdadeira ressurreição. Portugal acertou então o passo com a Europa (o desacêrto se dera sob a monarquia dual dos Filipes), adotando em meados do século XVIII o ideário iluminista; o pensamento nacional rejuvenesceu; o mercantilismo metalista, expandindo-se, deu nôvo alento à Metrópole e às Colônias; no Brasil, tivemos o surto realmente expressivo do arcadismo, com os grandes poetas mineiros; os oratorianos de S. Filipe Néri, substituindo-se aos jesuítas na educação da mocidade, prepararam o terreno à influência de Locke e de Descartes; Pombal, sob o govêrno cesarista combatido por Teófilo, realizou enfim a reforma da Universidade de Coimbra (1772), fato de importância capital para a evolução do pensamento e das ciências exatas na Península Ibérica. E mais não é preciso dizer.
A própria sociedade portuguêsa, enquanto eongresse eap̣ ritual, ganhou outra dimensão a partir do reinado joanino, 0 movimento academicista, com todas as vicisaitudes que teve de enfrentar, vazou também em nova forma o espirito oriador| e o avanço do «francesismo», com o Conde de Eriecira e seut continuadores, nos diz, contràriamente ao arrazondo de Teofilo, que não houve, de modo algum, sob $\mathrm{D}$. Joăo $\mathrm{V}$ e D. Josế $\mathrm{I}_{\text {, a }}$ alegada "pobreza e falta de idéias na literatura de Portugal.

As Vascongadas são um exemplo típico de resiatencia $a 0$ poder assimilador de Roma. O país basco refugou quante pôde o modêlo latino; e que é que produziu? Não há povo, na lịu ropa, que haja resguardado tanto quanto êle as suas origeni: A prevalecer, grosso modo, a opinião de Teófilo, seria êta 0 mais original do Continente. Sabemos que não o 6.10 sabeme日 também que, em matéria tão melindrosa, como esta que entende com a formação dos povos, não valem de modo algumi como argumento, generalizações como essa, brilhantel mai falhas de conteúdo.

De resto, a dinâmica da cultura apresenta outra complexil dade; nenhuma de suas formas vivas - tradições, idéias, tumes, criações literárias - pode isolar-se, voltar-se sôbre Gi mesma. Nesse processo, todo contacto é estimulante, E deve-äe atentar também em que, entre os fatôres mais vigorosamente atuantes no desenvolvimento de um povo, os de ordem politiea são muitas vêzes os menos importantes, dado que há um subia: trato nacional permanente, quase sempre rebelde a tôdas ai constrições ou deformações impostas pelo mecanismo goverua" mental.

O cesarismo de D. João V e D. José I durou 71 anos; nầ0 teria fôrças, evidentemente, para secar as fontes mais origi nais da literatura portuguêsa, condenando-a à «pobreza o falta de idéias», descoberta pelo citado crítico. O cesarismo dos Lul ses, em França, teria ocasionado a mesma devastação? Todoß sabemos que se deu o contrário: em vez de devastação, houve ressurgimento e esplendor.

Explica-se, porém, o equívoco. $\overline{\mathrm{E}}$ que o argumento prinelpal do autor da Visão dos Tempos está impregnado até à me. dula de prejuízos positivistas. São êstes prejuízos que invalidam 
a月 suas deduções, embora fique de pé uma afirmação de transecndente importância - Portugal, virando as costas ao ninho literírio galego, perdeu um filão original. Já que o historiador argumenta com hipóteses, no campo da história, recurso algo perigoso, seria o caso de perguntarmos: Teria sido, necessàriamente, mais rica e mais cheia de idéias a literatura portuguêsa, ลอ n⿺𠃊๋ se houvesse romanizado tão completamente a Península lbériea?

A originalidade da poesia galega passou em julgado. EnHetanto, quem nos prova que Portugal abandonou, como quer Teoffllo, êsse veio tradicional da sua lírica? O moçárabe consแнulu, $\delta$ eerto, um tipo também original de cultura, mas o fêz A margem da caudal procedente de além-Minho. A linfa da Cดลlıล não desapareceu - corre ainda, subjacente, assim como outras culturas da Europa e do Norte da Āfrica, lançadas no mesmo estuário peninsular.

Seja como fôr, o fato inconteste é que Portugal apresenta hoje, na Europa, uma fisionomia peculiar. Apertado entre o eipanhol ( $\alpha$ De Espanha nem bom vento, nem bom casamento», diи 0 rifoneiro) e o Mar Oceano, aquela pequena faixa de terra alaimilou as culturas que para lá convergiram, através de sua bofrida história, modelando uma resultante que lhe tem preiervado, a um só tempo, o caráter nacional e a ação ecumênica da вua gesta renascentista.

Isto $\delta$ o que mais importa. Ao assimilar, por exemplo, a Ingu latina, transformando-a neste «rude e doloroso idioma» que o nosso, Portugal preferiu a via mais universal, entre tantas que the ofertavam diferentes culturas em choque. Ante 0 İlă e o Cristianismo, ficou com êste último. Não há paralelo posivivel entro as duas culturas que Cristo e Maomé represenโละ. A universalidade do espírito, sua integração no transcendente da vida, a humanização do homem, por efeito de um tipo du moral que lenta e cotidianamente se aperfeiçoa, fugindo ao imebilismo - tudo doeumenta a superioridade do tipo de civilivaçî̀ trasido à Ibéria pelos romanos, a partir de Jallo César.

$O$ espaço português continental fol poue a pouee domi= ando pelas legióes romanas, e tho fundamente eavaram eatas, na infra-estrutura social, que as instituições visigóticas tiveram de adaptar-se ao modêlo latino; mas os novos Estados, surgidos na península, depois da longa dominação muçulmana, não puderam também fazer tábula rasa da sedimentação a que presidira o espírito latino e cristão.

O Renascimento, em Portugal, apura o traço cristão, o seu poder germinativo na conquista das almas; e, por isso, quando no seu poema Camões se refere à dilatação «da fé e do império», não exprime uma palavra vã.

A história moderna, na linha do pensamento materialista, tem-se esforçado por diminuir a importância do elemento religioso na expansão ultramarina de Portugal. Tôda uma corrente df modernos historiadores, alguns de grande mérito, revê neste momento o processo dos descobrimentos, à luz da geografia econômica do Norte da Äfrica. Os professôres Vitorino MagaIhães Godinho e A. H. de Oliveira Marques, por exemplo, mostraram já até que ponto o trigo norte-marroquino e o ouro do Sudão, ambos transportados para os portos do Mahgreb, tiveram imediata ação propulsora, no sentido de atritar culturas hostis - o crente muçulmano e o representante da feudalidade européia, e em especial da portuguêsa.

Saindo das limitações territoriais, que a inclinavam a ser mero apêndice de outras nações, a recém-formada nação lusa se credenciara a multiplicar muitas vêzes o seu espaço originário, levando aos demais continentes a cultura latina.

Nunca realizara nenhum povo tamanho esfôrço de transplantação, em condições tão diversas e sob tão diferentes climas. O espírito particularista, tão vivo ainda mesmo na Espanha de hoje, não acha validade, não se sustém em Portugal. Lar exíguo, espaço quase uniforme, Portugal só se divide, em verdade, conforme o demonstrou lùcidamente Orlando Ribeiro, em duas partes: - Portugal mediterrâneo e Portugal atlântico. A natureza, quero dizer, o revestimento vegetal - produto de civilização, no caso - lá está para o documentar. E o sentido da eultura que os portuguêses espalharam pelo mundo obedece também a êsase movimento pendular - do Mediterrâneo para a: terras atiantieas do Sul, Quer diner! a latinidade, na sua 
projeģão ocidental, encontrou na pequena casa portuguêsa o lume que generosamente a reanimou, espalhando-a depois, transfigurada, pelo resto do orbe.

Mas isto não se deu por nenhum milagre. Foi obra dos homens, da paciente tenacidade com que os «barões», em outra lidade que não a nossa, afeiçoaram ao seu solo essa cultura lalina, maturando-a, experimentando-a, amassando-a com suor e lígrimas. Povo de agricultores, o português recebe a inclemêneia do tempo com resignação e esperança; não perde o fio de prumo, não braceja; confia em si mesmo, na sua resistência. ถล สนล espantosa capacidade de afrontar a privação e a des-

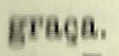

Por essas qualidades tôdas, ampliou pacientemente o seu e๔paço moral, político e literário. Moralmente, insere-se na trađiẹto oristã, tal como os romanos a preservaram; politicament6, \& herdeiro das instituições romano-góticas, afeiçoadas a uma realidade em tudo diferente da que the ofereceu a orgulinesa Roma imperial; literàriamente, por fim, o povo português evoluiu também no sentido da latinidade, a saber: da clareza das idéias, da forma geométrica, da economia verbal, do senso de proporção greco-romano. E não estará aí, nessa direção, o ponto mais alto a que pode aspirar o homem, na sua tarefa eivilianadora?

Voltando, pois, ao ponto inicial: Não tem razão Teófilo Hrage quando diz que os «reis portuguêses, ligados com a aristoeracia asturo-leonesa [...] cometeram o êrro desastroso de aถerifiearem a vida e criação do moçárabe à caduca civilização Fomanas,

Caduca? Mas, como? Uma civilização não é um corpo físico, a naseimento, desenvolvimento e morte. Não. Uma civilização ê um processo, uma constante transmutação de valôres. Nada hí de fixo no Ámbito da cultura. As culturas se interpenetram, jamaí se anquilosam; săo, antes, fôrças sempre em movimento, gerando outras soluçōes e comportamentos, numa vivaeidade

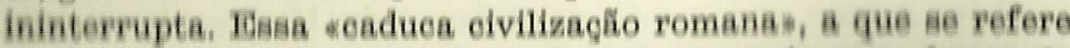
o eseritor, năอ fol sento o sinal de que aur
Roma, o vasto mundo latino, de que Portugal se fêz mensageiro, transportando aos quatro cantos, na asa das suas caravelas, a mensagem da concepção cristã de vida.

Nem sempre tal mensagem estêve isenta das limitações ditadas pela ruim paixão de um que outro príncipe, de um que outro rude e cruel cabo-de-guerra, de um que outro apóstolo desumanizado pelo fanatismo. Mas isto não quer dizer que a Nação haja deixado de cumprir, como conjunto a operar no largo espaço em que se dilatou, um nobilíssimo programa de implantação do humanismo latino e cristão, em todos os sítios até onde foi possível chegar a ousadia do luso. 